\title{
Can Capital Injection Make Challenged Gold Projects in Ghana Economically Viable? - A Case Study*
}

\author{
${ }^{1}$ D. Mireku-Gyimah and ${ }^{1}$ R. Gyebuni \\ ${ }^{1}$ University of Mine and Technology, P. O. Box 237, Tarkwa
}

Mireku-Gyimah, D. and Gyebuni, R. (2019), "Can Capital Injection Make Challenged Gold Projects in Ghana Economically Viable? -A Case Study", Ghana Mining Journal, Vol. 19, No. 1, pp. 42 - 48.

\begin{abstract}
Damang Gold Mine (DGM) in Ghana uses open pit mining technology to mine its gold deposit. It has an estimated mineable gold reserve of about $32 \mathrm{Mt}$ exploitable for 8 years. As the gold price kept falling from 2013 and operating cost kept rising, the mine down sized its operations. But the operations became challenging due to poor performance of ageing mining equipment and processing plant, and the need for a new tailings dam. As the gold price stabilises, it could be gainful to invest capital to resolve the challenges and increase production. This study aims at investigating whether DGM would be economically viable if the intended investment is made assuming the gold price falls to US $\$ 32.15 / \mathrm{g}$. The study estimates the required capital and annual operating cost to be US\$89.49 M and US\$100.84 M respectively. A cash flow analysis is carried out assuming no price escalation, discount rate of $20 \%$, and applying the following investment laws of Ghana: royalty of $5 \%$ of gross revenue; straight line depreciation of capital expenditure over five years (20\% per year); investment allowance of $5 \%$ in the first year only; loss carry forward; and corporate tax of 35\%. The results give Net Present Value of US\$82 723 720.28 and Internal Rate of Return of $41.13 \%$, indicating profitability. Sensitivity analysis reveals that the project will continue to be profitable until the revenue falls below $24 \%$, assuming all other economic parameters remain constant. The project will also continue to be profitable until the operating cost increases beyond $30 \%$, assuming all other economic parameters remain constant. Risk analysis on the project indicates the project has $70 \%$ chances of success. DGM could invest the capital to mine its gold reserves because the mine will make profit provided cost is controlled and production level maintained to generate needed revenue.
\end{abstract}

Keywords: Net Present Value, Internal Rate of Return, Sensitivity Analysis, Risk Analysis

\section{Introduction}

The Damang Gold Mine (DGM) of Abosso Goldfields Limited uses open pit mining technology to mine its oxide and fresh gold deposit. The run-of-mine ore is processed by a carbon-inleach processing plant. The mine has a gold reserve of $32 \mathrm{Mt}$ which can be exploited for 8 years (Anon., 2015). When the gold price started falling from 2013 and operating cost kept rising, the mine down sized its operations. Continued operations became challenging due to the poor performance of ageing mining equipment, processing plant with the associated high maintenance costs, and the need for the construction of a tailings storage facility as the existing almost got full. To deal with these challenges and still make profit, a capital injection of US\$89.49 $\mathrm{M}$ and an annual operating cost of US $\$ 100.84 \mathrm{M}$ are required. With the gold price is stabilising, DGM would like to invest capital to solve the problems of the ageing mining equipment and processing plant and construct a new tailings dam. It is expected that after solving these problems, production can be increased to generate sufficient revenues and so make DGM a profitable mine. To this end, an economic evaluation is required to ascertain the profitability of such an investment. This work thus aims at investigating whether DGM would be economically viable if the intended investment is made, assuming the gold price even falls further to stabilise at US\$ $32.15 / \mathrm{g}$ (US\$ 1000/oz).

Damang is located near Tarkwa in the Western Region of Ghana (See Fig. 2.1). DGM concession covers a total area of 25016 ha. According to Kesse (1985), the Damang orebody lies within the Tarkwaian System, which forms a significant portion of the stratigraphy of the Ashanti Belt in southwest Ghana, and is hosted by north to northwesterly plunging antiform developed within Tarkwaian rocks.

The main Damang pit is located close to the closure of the antiform and all other known mineralisation is located on the east and west limbs of the Damang anticline. The antiformal closure plunges shallowly to the north, whereas the eastern and western limbs of the antiform dip steeply to the east and west respectively. DGM exploits oxide and fresh hydrothermal mineralisation in addition to Witwatersrand style palaeoplacer mineralisation.

DGM experiences a tropical climate, characterised by two distinct rainy seasons from March to July, and September to November. Average annual rainfall in the area is $2030 \mathrm{~mm}$. Temperatures are high throughout the year and range from $23{ }^{\circ} \mathrm{C}$ to $28{ }^{0} \mathrm{C}$ (Anon., 2015). Although there are few disruptions to mining operations during the wet season, production continues throughout the year. 


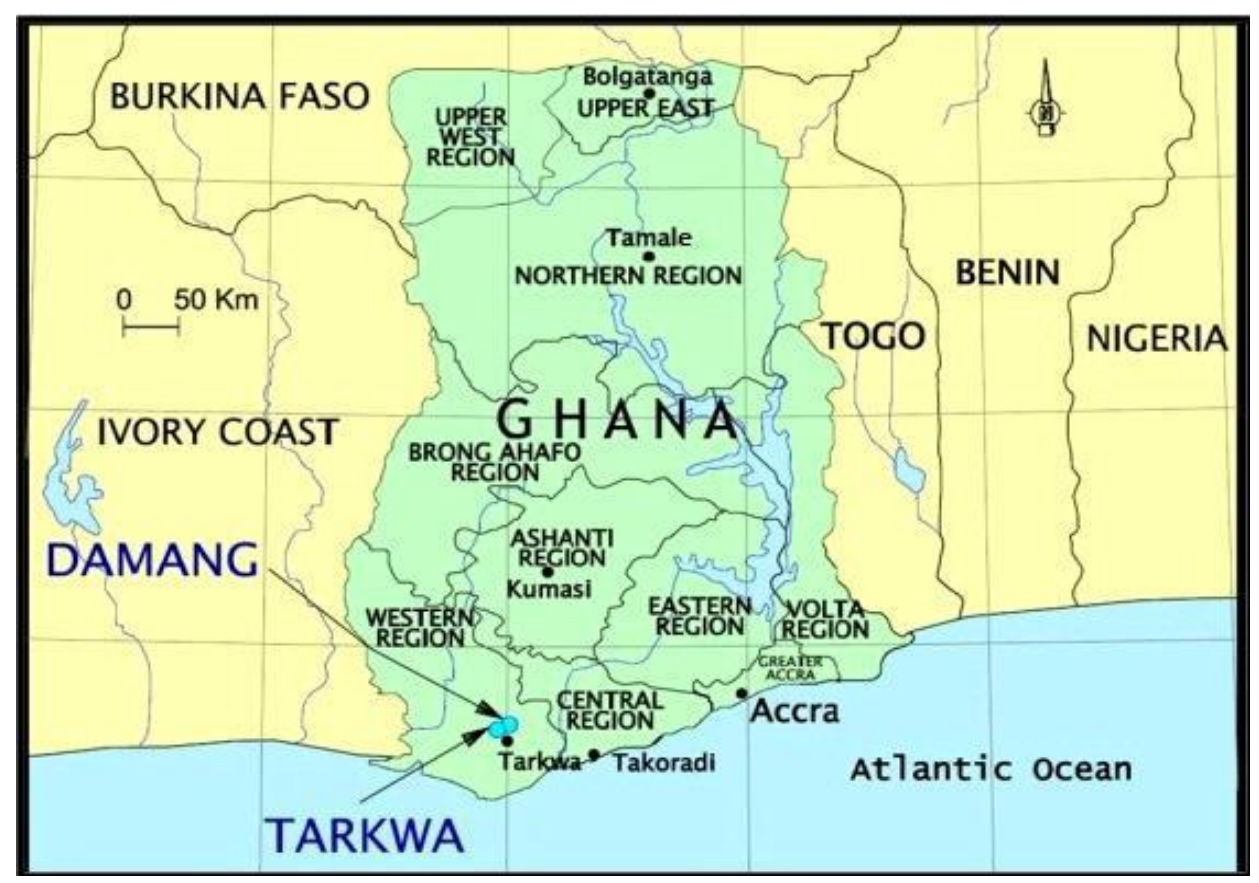

Fig. 1 Location of Damang on the Map of Ghana

\section{Resources and Methods Used}

\subsection{Materials}

The data used in this study includes reports on the mineral reserves of DGM, mill production capacity, assumed gold price of US\$ $32.15 / \mathrm{g}$, unit cost data, method of financing in addition to the other operating cost parameters of the mine.

\subsection{Methods}

\subsubsection{Revenue Estimate}

The gross revenue for each operating year is estimated using Equation 1 (Mireku-Gyimah, 2016):

$$
R=[(T)(1-L)(1+D)](G)(r)(P)
$$

where

$\mathrm{T}=$ Tonnage of ore produced per year $(\mathrm{t} / \mathrm{yr})$;

$\mathrm{G}=$ Mill head grade $(\mathrm{g} / \mathrm{t})$;

$\mathrm{r}=$ Mill recovery (in decimal);

$\mathrm{P}=$ Unit price of processed ore (US\$/g);

$\mathrm{L}=$ Ore loss (in decimal); and

$\mathrm{D}=$ Ore dilution (in decimal).

\subsubsection{Capital Cost Estimate}

The entire re-evaluation exercise of the mine is necessitated by the challenges of the aged processing plant and mining fleet, and exhausted tailings storage facility, all in the face of the falling gold price. The major cost drivers are thus pronounced in these areas where a new sag mill is to be bought, a tailings dam built and actual mining done using contractor equipment. The capital costs are grouped into the following categories (see Table 1):

(i) Pre-production Cost;

(ii) Direct Capital Cost;

(iii) Indirect Capital Cost; and

(iv) Allowances.

Each of the categories has definite costs estimated using detail cost estimation method.

\subsubsection{Operating Cost Estimate}

In estimating the operation costs, it is assumed that both skilled and unskilled labour are available in Ghana. Therefore, mainly local employees will be used for the project. The remuneration for employees is determined by consultation between Mine Workers Union and DGM. The estimates are based on a working regime of two shifts per day, ten hours per shift, and 350 days per year. The annual operating costs are summarised in Table 2 .

\subsubsection{Investment Decision Criteria}

The following general investment criteria are used in this study (Mireku-Gyimah, 2016):

(i) If a project's NPV is positive (NPV $>0)$, the project is considered to be economically 
acceptable. When the NPV is zero (NPV = 0 ), the project breaks even. When the NPV is negative $(\mathrm{NPV}<0)$, the project is considered to be economically unacceptable; and

(ii) If a project's IRR is greater than the minimum rate of return (MRR), i.e. (IRR > MRR), the project is considered to be economically acceptable. When the IRR is equal to the minimum rate of return $(\mathrm{IRR}=\mathrm{MRR})$, the project breaks even. When the IRR is less than the minimum rate of return (IRR < MRR), the project is considered to be economically unacceptable.

\subsubsection{Cash Flow (CF) Analysis}

Cash flow is explained as the difference between the total cash receipts (inflows) and total cash disbursements (outflows) for a given period of time, typically one year (Stermole and Franklin, 1993). Mathematically, cash flow may be expressed as follows (Equation 2):

$\mathrm{CF}=\sum$ (Cash Inflows $)-\sum$ (Cash Outflows)

Table 1 Details of Capital Cost Estimate

\begin{tabular}{|c|c|}
\hline Cost Centre & Amount (US\$ $\left.\times 10^{6}\right)$ \\
\hline $\begin{array}{l}\text { Pre-production Cost } \\
\text { Exploration, and } \\
\text { Consultancy } \\
\text { Re-investment Studies } \\
\text { Advanced Exploration } \\
\text { Drilling } \\
\text { Private Consultant }\end{array}$ & $\begin{array}{l}1.70 \\
1.50 \\
1.40\end{array}$ \\
\hline $\begin{array}{l}\text { Direct Capital Cost } \\
\text { Mining } \\
\text { Contractor Moblisation } \\
\text { Construction } \\
\text { Development } \\
\text { Sterilisation drilling }\end{array}$ & $\begin{array}{l}1.00 \\
1.50 \\
0.80\end{array}$ \\
\hline $\begin{array}{l}\text { Processing Plant } \\
\text { SAG Mill and Crusher } \\
\text { Tailings Dam }\end{array}$ & $\begin{array}{c}5.10 \\
57.40\end{array}$ \\
\hline $\begin{array}{l}\text { Infrastructure and Site } \\
\text { Works } \\
\text { Site Development } \\
\text { Workshop } \\
\text { Vehicles } \\
\text { Refurbishment of } \\
\text { Accommodation }\end{array}$ & $\begin{array}{l}2.70 \\
1.60 \\
0.80 \\
1.10\end{array}$ \\
\hline $\begin{array}{l}\text { Indirect Capital Cost } \\
\text { Compensations } \\
\text { Environmental } \\
\text { Protection }\end{array}$ & $\begin{array}{l}0.80 \\
0.40\end{array}$ \\
\hline $\begin{array}{l}\text { Allowances } \\
\text { Contingency }(15 \%)\end{array}$ & 11.69 \\
\hline Total Capital Cost & 89.49 \\
\hline
\end{tabular}

Table 2 Summary of the Annual Operating Cost

\begin{tabular}{|l|c|}
\hline Cost Centre & Amount (US\$ x 10 \\
\hline Mining & 47.00 \\
\hline Treatment Plant & 33.80 \\
\hline Overheads & 2.54 \\
\hline Contingency (15\%) & 12.50 \\
\hline Total & $\mathbf{1 0 0 . 8 4}$ \\
\hline
\end{tabular}

The annual revenue from a viable venture should be able to pay for operating cost and all other liabilities such as royalties before tax obligations are fulfilled and any interest on loan paid.

According to McDivitt and Jeffery (1976), a very economically attractive investment may be rejected for financial or intangible reasons; e.g. taxes on mining ventures could go up as high as $80 \%$ in Chile in the 1950s. The Government of Ghana, however, allows for depreciation, depletion, amortisation, and other deferred deductions on mining businesses to enable them recover the cost of the huge investments made. Therefore, taking into consideration the fact that DGM is located in Ghana, the following mineral investment laws are applied in calculating the yearly cash flows:

(i) Royalty: Any mineral project in Ghana must pay a flat royalty rate of $5 \%$ on the gross revenue to the Ghana government.

(ii) Income Tax: An operating mine is by law expected to pay income tax of $35 \%$.

(iii) Windfall Tax (WT): An operating mine is required to pay a windfall tax at the rate of $10 \%$. The WT is payable on the CarryForward Cash Balance (CFCB) which can be calculated as: $\mathrm{CFCB}=\mathrm{TI}-(\mathrm{IT}+\mathrm{CI}+\mathrm{AI})$ $+(\mathrm{I}+\mathrm{CA}+\mathrm{LF})$, where $\mathrm{TI}$ is the taxable income, IT is the income tax, CI is the capital invested, AI is the addition to inventory, I is the interest paid on capital, CA is the capital allowances, all in the year of assessment, and LF is the loss brought forward from the previous year. Though Windfall Tax is currently not enforced in Ghana, it is captured here as a precautionary tax component.

(iv) Capital Allowance: An operating mine is entitled to a capital allowance which is a straight-line depreciation of capital expenditure over 5 years (20\% per year).

(v) Investment allowance of 5\% is allowed in the 1st year only.

(vi) Loss Carry-Forward: An operating mine is entitled to carrying forward the loss incurred in a particular year of assessment to the next year, except that the amount carried forward should not exceed the capital allowance (depreciation) in that year. 
The cash flow analysis is based on the following assumptions:

(i) Base gold price is fixed at US\$ $32.15 / \mathrm{g}$;

(ii) The minimum rate of return is $20 \%$;

(iii) Working capital is $10 \%$ of the operating cost; and

(iv) The project is $100 \%$ equity funded.

\subsubsection{Sensitivity Analysis}

Sensitivity Analysis is done to determine the effect of changes in a selected economic parameter on the economic viability of the project while all other economic parameters remain constant. In this study, sensitivity analysis is conducted to investigate the effect of changes in capital cost, operating cost and revenue on the economic viability of the project. This is carried out by varying one of the economic parameters by $\pm 20 \%$ intervals up to $\pm 60 \%$ while keeping the other parameters constant and calculating the NPV and IRR consequent to the changes.

\subsubsection{Risk Analysis}

Risk can be defined as follows (Eshun, 2007):

(i) The dispersion of the probability distribution of a variable, the value of which is being predicted;

(ii) Uncertainty associated with the financial outcome of a particular investment proposal; or

(iii) The probability of occurrence of different values of each investment parameter.

Each of these definitions attests to the fact that risk is a measure of uncertainty. Two main risks are associated with mining projects, vis: country risk and mineral project risk.

Country risk can be political, geographical, economic or social. Instability of tax rates, foreign ownership policy and unstable governments constitute sources of political risk. Smith and Kerry (1982) suggest that a higher discount rate should always be selected to account for country risk since it is very difficult to quantify.

Mineral risk, however, can be quantified economically and analysed. Mineral project risk factors include uncertainties associated with the estimation of grade, tonnage, mine life, revenues, capital and operating costs. It also includes the possibility of poor mine recovery and high dilution as a result of geological conditions, unsuitable mining system, and poor mining sequence to meet production schedules. This study uses the Monte Carlo simulation method, which is widely accepted for mineral project risk analysis (Eshun, 2007), to determine the risk associated with the DGM recapitalisation project. In all, 500 iterations are run to generate simultaneous random values for each of revenue, operating cost and capital cost. The simultaneous effects that the input variables have on the profitability of the project are then determined. Frequency distribution curves are generated for each of the profit indicators (IRR and NPV) using their mean values. The probabilities of success and failure are inferred from the cumulative frequency distribution curves.

\section{Results and Discussion}

From Equation (1) the gross revenue for each operating year was calculated using the data:

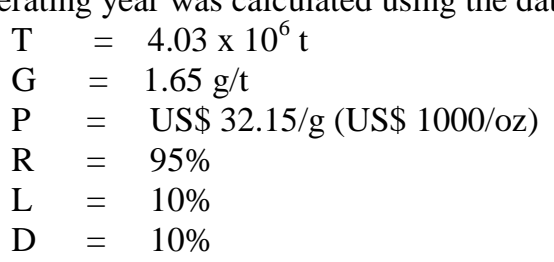

$$
\begin{aligned}
R & =[(4030000)(1-0.1)(1+0.1)](1.65)(0.95)(32.15) \\
& =\mathrm{US} \$ 201061430.21
\end{aligned}
$$

In the first year however, when the mine would process low grade ore from the stockpiles, at an average of $0.91 \mathrm{~g} / \mathrm{t}$, revenue will be:

$$
\begin{aligned}
R & =[(4030000)(1-0.1)(1+0.1)](0.91)(0.95)(32.15) \\
& =\mathbf{U S \$ 1 1 0 ~ 8 8 8 ~ 4 2 5}
\end{aligned}
$$

From Table 2, it can be seen that the annual operating cost is US\$ $100.84 \times 10^{6}$ obtained by using detailed cost estimation method.

Table 1 presents the capital cost estimate. It can be deduced that the total capital cost of the project is US\$ $89.49 \times 10^{6}$. DGM has decided to fund the project with $100 \%$ equity.

The annual production rate is $4.03 \mathrm{Mt}$ and with a total mineable reserve of $31.50 \mathrm{Mt}$, the life of mine (L), is calculated thus:

$$
L=\frac{31.50 \times 10^{6}}{4.03 \times 10^{6}}=8 \text { years }
$$

Thus, the cash flow analysis over 8-year period is carried out using the following estimated values as the base scenario:

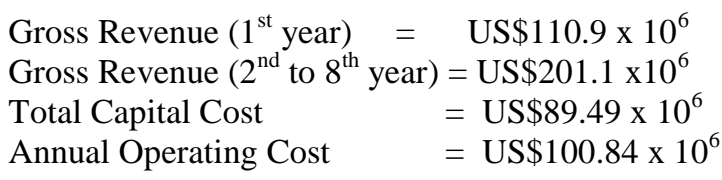


The results of the cash flow analysis are summarised in Table 3. It is observed from the results that the mine has a Net Present Value (NPV) of US\$82 723720.28 and Internal Rate of Return (IRR) of $41.13 \%$. Since the NPV $>0$ and the IRR $>M R R$, it can be resolved that the mine is profitable.

The results of the sensitivity analysis are presented in Figs. 2 and 3 for NPV and IRR respectively. The results show that:

(i) If all other economic parameters remain constant, the mine can withstand up to $24 \%$ drop in revenue and still be profitable; (ii) If all other economic parameters remain constant, the mine can withstand up to $30 \%$ increase in operating cost and still be profitable; and

(iii) The mine is not very sensitive to capital cost; increase in capital cost by say $30 \%$ can be accommodated, if need be.

The results of the risk analysis performed on the project are presented as cumulative frequency distributions of NPV and IRR in Figs. 4 and 5 respectively. The risk profiles indicate that the probability of failure, i.e the probability that $\mathrm{NPV} \leq 0$, and $\mathrm{IRR} \leq \mathrm{MRR}$ is $30 \%$; which implies that probability of success is $70 \%$.

\section{Table 3 Cash Flow Analysis for Damang Mine (Base Case Scenario)}

\begin{tabular}{|c|c|c|c|c|c|c|c|c|c|}
\hline Equity Capital =100\% & $=$ US $\$ 89,490,000.00$ & Production(Yr1)@ 0.91g/t & $=4,030,000 \mathrm{t}$ & Project Life & $=8 \mathrm{yrs}$ & & & & \\
\hline Loan Capital $=0 \%$ & $=$ US $\$ .00$ & Production (Yr2-8) & $=4,030,000 t$ & Interest Rate & $=0 \%$ & & & & \\
\hline Gold Price & $=U S \$ 32.15 / \mathrm{g}$ & Grade (Yr2-8) & $=1.42 \mathrm{~g} / \mathrm{t}$ & DiscountRate & $=20 \%$ & & & & \\
\hline Total Capital Investment & $=$ US $\$ 89,490,000.00$ & Recovery & $=95 \%$ & Percentage Loan & $=0 \%$ & & & & \\
\hline Working Capital & $=$ US $\$ 10,084,000.00$ & Dilution & $=10 \%$ & & & & & & \\
\hline Annual Operating Cost(per yr) & $=$ US $\$ 100,840,000.00$ & Ore Loss & $=10 \%$ & & & & & & \\
\hline them Year & 0 & 1 & 2 & 3 & 4 & 5 & 6 & 7 & 8 \\
\hline Gross Revenue (Sr) & 0.00 & $110,888,425.00$ & $201,061,430.21$ & $201,061,430.21$ & $201,061,430.21$ & $201,061,430.21$ & $201,061,430.21$ & $201,061,430.21$ & $201,061,430.21$ \\
\hline \multicolumn{10}{|l|}{ Less: } \\
\hline Royalty, $\mathrm{Rt}=\mathrm{ro}^{*} \mathrm{Sr}$ & 0.00 & $5,544,421.25$ & $10,053,071.51$ & $10,053,071.51$ & $10,053,071.51$ & $10,053,071.51$ & $10,053,071.51$ & $10,053,071.51$ & $10,053,071.51$ \\
\hline Operating Cost (Opcost) & 0.00 & $100,840,000.00$ & $100,840,000.00$ & $100,840,000.00$ & $100,840,000.00$ & $100,840,000.00$ & $100,840,000.00$ & $100,840,000.00$ & $100,840,000.00$ \\
\hline Net Revenue (Rn) & 0.00 & $4,504,003.75$ & $90,168,358.70$ & $90,168,358.70$ & $90,168,358.70$ & $90,168,358.70$ & $90,168,358.70$ & $90,168,358.70$ & $90,168,358.70$ \\
\hline \multicolumn{10}{|l|}{ Less: } \\
\hline \begin{tabular}{|l|} 
Investment Allowance \\
\end{tabular} & & $4,474,500.00$ & 0.00 & 0.00 & 0.00 & 0.00 & 0.00 & 0.00 & 0.00 \\
\hline Capital Allowance (Depreciation) & & $17,898,000.00$ & $17,898,000.00$ & $17,898,000.00$ & $17,898,000.00$ & $17,898,000.00$ & 0.00 & 0.00 & 0.00 \\
\hline Interest & 0.00 & 0.00 & 0.00 & 0.00 & 0.00 & 0.00 & 0.00 & 0.00 & 0.00 \\
\hline Loss Carry Forward & 0.00 & 0.00 & $17,868,496.25$ & 0.00 & 0.00 & 0.00 & 0.00 & 0.00 & 0.00 \\
\hline Taxable Income (Ti) & 0.00 & $-17,868,496.25$ & $54,401,862.45$ & $72,270,358.70$ & $72,270,358.70$ & $72,270,358.70$ & $90,168,358.70$ & $90,168,358.70$ & $90,168,358.70$ \\
\hline \multicolumn{10}{|l|}{ Less: } \\
\hline Tax (35\% of Ti) & 0.00 & 0.00 & $19,040,651.86$ & $25,294,625.54$ & $25,294,625.54$ & $25,294,625.54$ & $31,558,925.54$ & $31,558,925.54$ & $31,558,925.54$ \\
\hline Net Income & 0.00 & $-17,868,496.25$ & $35,361,210.59$ & $46,975,733.15$ & $46,975,733.15$ & $46,975,733.15$ & $58,609,433.15$ & $58,609,433.15$ & $58,609,433.15$ \\
\hline \multicolumn{10}{|l|}{ Add: } \\
\hline Investment Allowance & 0.00 & $4,474,500.00$ & 0.00 & 0.00 & 0.00 & 0.00 & 0.00 & 0.00 & 0.00 \\
\hline Capital Allowance & 0.00 & $17,898,000.00$ & $17,898,000.00$ & $17,898,000.00$ & $17,898,000.00$ & $17,898,000.00$ & 0.00 & 0.00 & 0.00 \\
\hline Loss Carry Forward & 0.00 & 0.00 & $17,868,496.25$ & 0.00 & 0.00 & 0.00 & 0.00 & 0.00 & 0.00 \\
\hline Working Capital (Last year only) & 0.00 & 0.00 & 0.00 & 0.00 & 0.00 & 0.00 & 0.00 & 0.00 & $10,084,000.00$ \\
\hline \multicolumn{10}{|l|}{ Less: } \\
\hline \begin{tabular}{|l} 
Loan Principal Repayment \\
\end{tabular} & 00.00 & 00.00 & 0.00 & 00.00 & 00.00 & 00.00 & 00.00 & 00.00 & 00.00 \\
\hline Equity Capital & $89,490,000.00$ & 00.00 & 00.00 & 00.00 & 00.00 & 00.00 & 00.00 & 00.00 & 00.00 \\
\hline Working Capital (first year only) & 0.00 & $10,084,000.00$ & 0.00 & 0.00 & 0.00 & 0.00 & 0.00 & 0.00 & 0.00 \\
\hline Windfall Tax $(10 \%)$ & 0.00 & 0.00 & $7,112,770.68$ & $6,487,373.32$ & $6,487,373.32$ & $6,487,373.32$ & $5,860,943.32$ & $5,860,943.32$ & $5,860,943.32$ \\
\hline CASH FLOW (CF) & $-89,490,000.00$ & $-5,579,996.25$ & $64,014,936.16$ & $58,386,359.84$ & $58,386,359.84$ & $58,386,359.84$ & $52,748,489.84$ & $52,748,489.84$ & $62,832,489.84$ \\
\hline NPV @ 20\%= & $\$ 82,723,720.28$ & & & & & & & & \\
\hline $\operatorname{RR}=$ & $41.13 \%$ & & & & & & & & \\
\hline
\end{tabular}

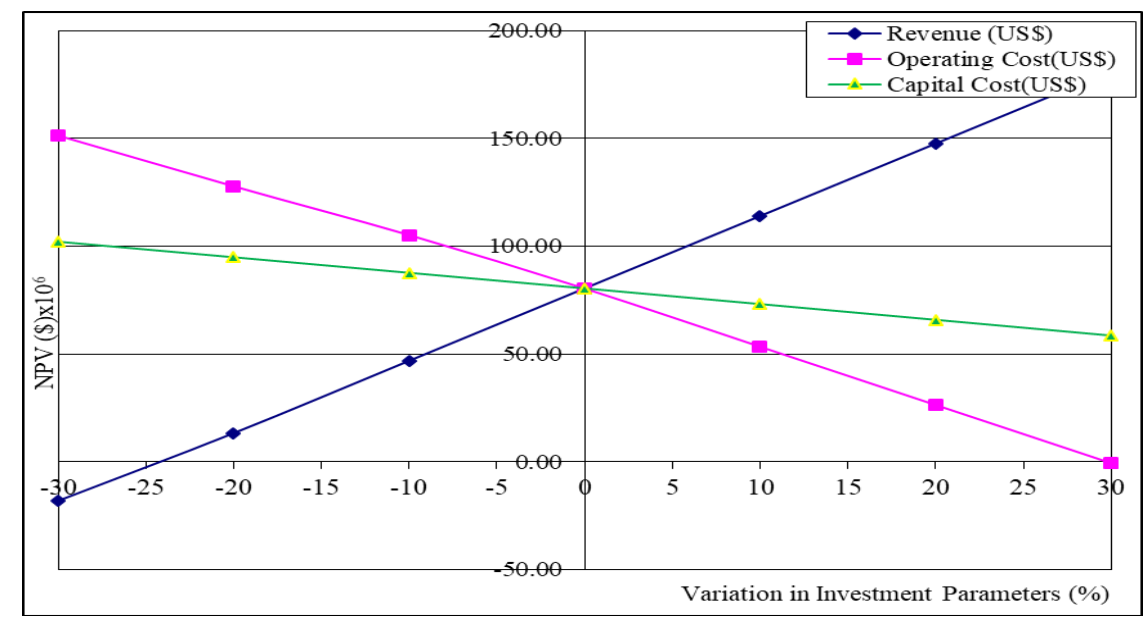

Fig. 2 Effect of Changes in Economic Parameters on NPV 


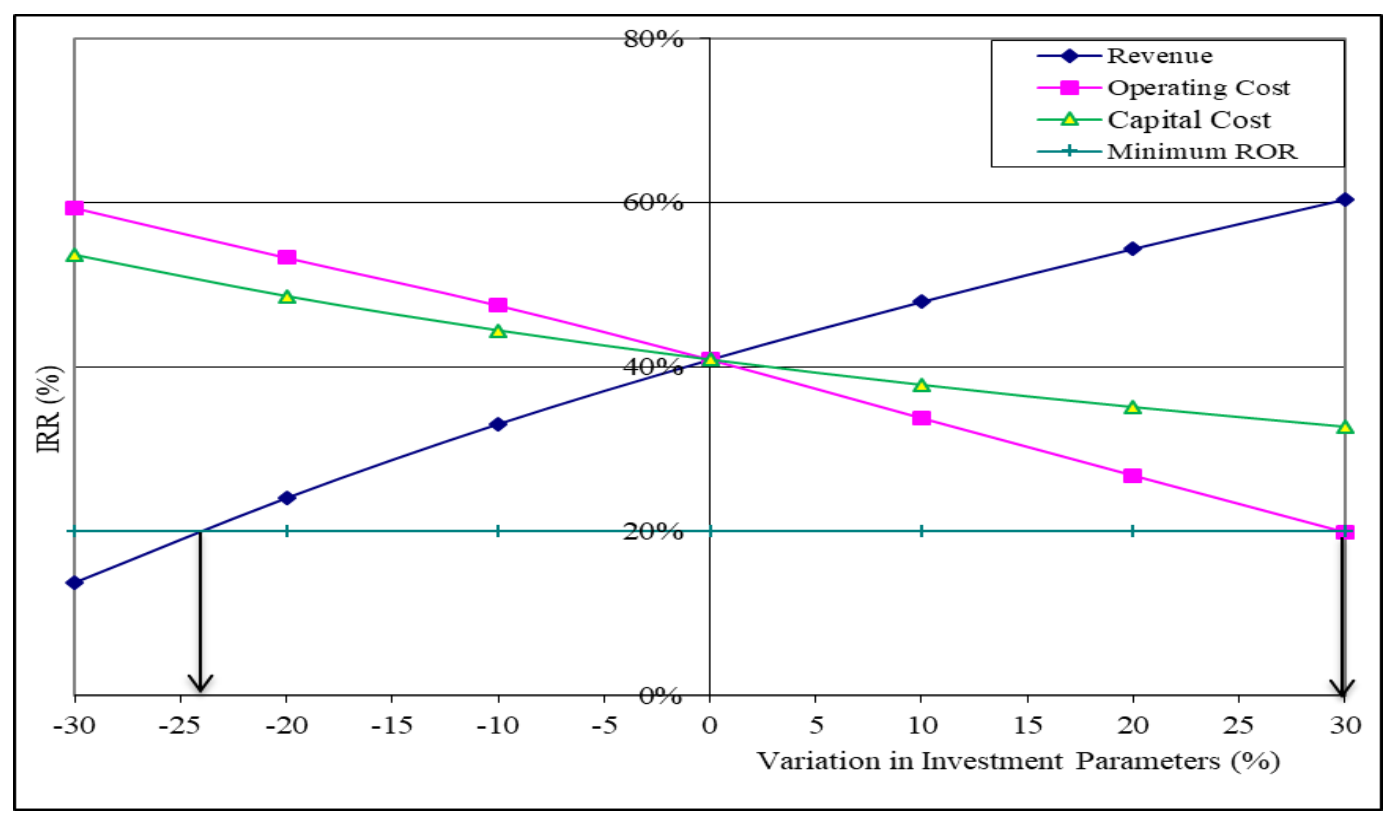

Fig. 3 Effect of Changes in Economic Parameters on IRR

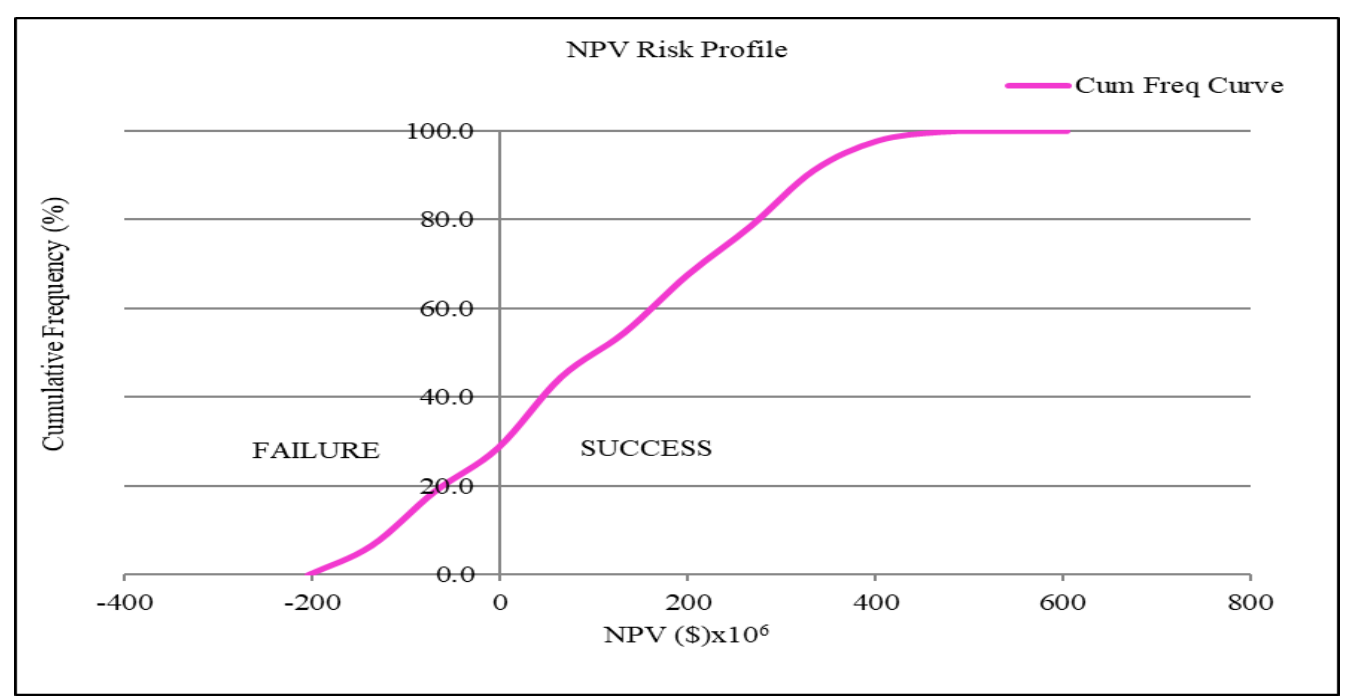

Fig. 4 Cumulative Frequency Distribution of NPV Index

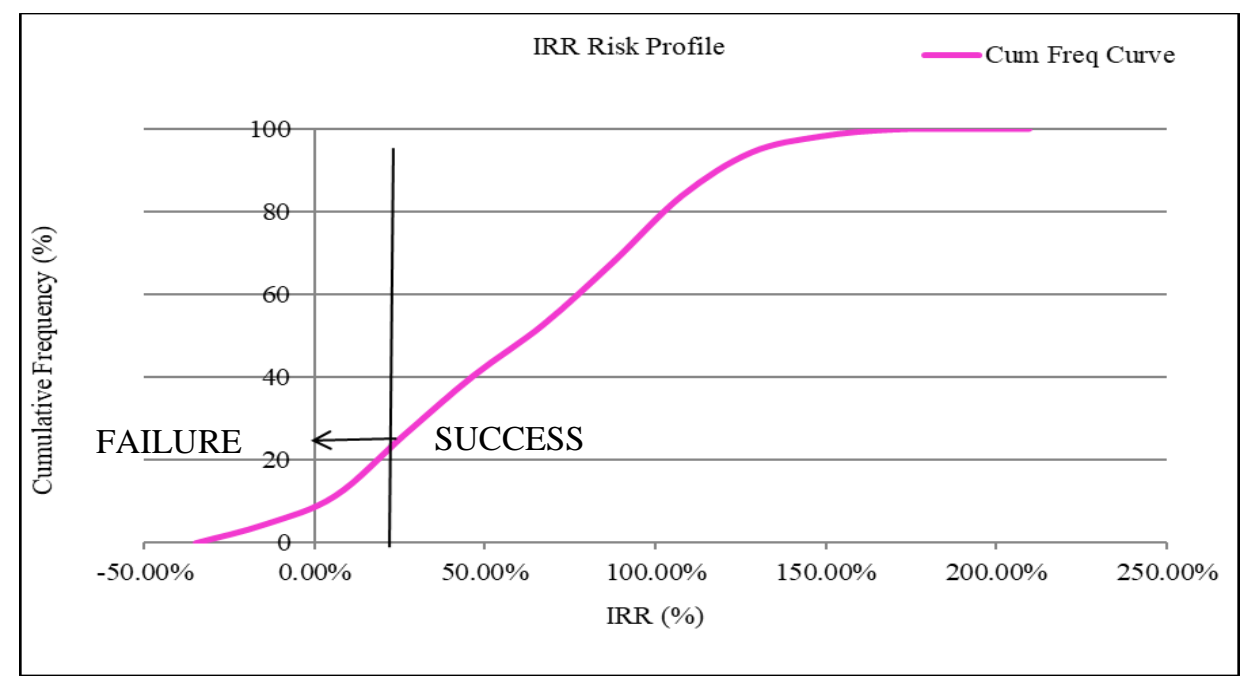

Fig. 5 Cumulative Frequency Distribution of IRR Index 


\section{Conclusions and Recommendation}

\subsection{Conclusions}

The following conclusions are drawn from the study:

(i) The mineable (proven and probable) reserves are $31.5 \mathrm{Mt}$ with an average grade of $1.65 \mathrm{~g} / \mathrm{t}$ (for $2^{\text {nd }}$ to $8^{\text {th }}$ year only). These reserves are to be mined at a production rate of $4.03 \mathrm{Mt}$ per year using open-pit mining method. The run-off-mine ore is to be treated by carbonin-leach processing plant.

(ii) The capital investment required for the mining of the deposit is US\$89.49 $\times 10^{6}$. The annual operating cost is US\$100.84 x $10^{6}$.

(iii) The results of the cash flow analysis show that, with a gold price of US\$ $32.15 / \mathrm{g}$ (US\$ $1000 / \mathrm{oz}$ ) and a minimum rate of return of $20 \%$, the project's Net Present Value (NPV) and Internal Rate of Return (IRR) are US $\$ 82$ 723720.27 and $41.13 \%$ respectively. These results give an indication of profitability.

(iv) Sensitivity analysis shows that the project will continue to be profitable until revenue falls below 24\%, assuming all other economic parameters remain constant. The project will also continue to be profitable until the operating cost increases beyond $30 \%$, assuming all other economic parameters remain constant.

(v) A risk analysis performed on the project using Monte Carlo simulation method indicates $70 \%$ probability of success and $30 \%$ failure.

\subsection{Recommendation}

It is recommended that DGM should go ahead and invest capital to mine the gold reserves because, all things being equal, the mine will make profit as long as cost control measures are implemented to ensure that the operating cost does not increase beyond $30 \%$ and efforts made to control grade and maintain ore supply of $4.03 \mathrm{Mt}$ per year to ensure that revenue does not fall below $24 \%$.

\section{Acknowledgements}

Appreciation goes to DGM for allowing the data to be used. Special gratitude is owed the Planning Team of DGM for their assistance.

\section{References}

Anon. (2015), Competent Person's Report, Damang CPR C2015_Final Draft, Abosso Goldfields Limited, Damang, 139 pp.
Eshun, P. A. (2007), "Mine Economic and Financial Evaluation', BSc Lecture Notes, University of Mines and Technology, Tarkwa, 128 pp.

Kesse, G. O. (1985), The Mineral and Rock Resources of Ghana, A. A. Balkema Publishers, Rotterdam, pp. 5 - 13 .

McDivitt, J. F. and Jeffery, W. G. (1976), Minerals and the Developing Economies, Vogley, W. A. and Riser, H. E. (eds.), American Institute of Mining, Metallurgical and Petroleum Engineering Inc., New York, pp. 3 - 32.

Mireku-Gyimah, D. (2016), "Mine Economic and Financial Evaluation', MSc Lecture Notes, University of Mines and Technology, Tarkwa, $128 \mathrm{pp}$.

Stermole, J. M. and Franklin, J. (1993), Economic Evaluation and Investment Decision Methods, Investment Evaluation Corporation, Colorado, $8^{\text {th }}$ ed., 648 pp.

Smith, J. V. and Kerry, S. V. (1982), Exploration in Natural Resources Economics, Hopkins University Press, Baltimore, 352 pp.

\section{Authors}

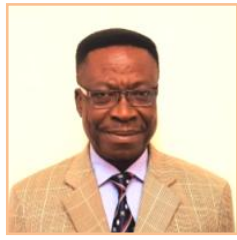

D. Mireku-Gyimah is a Professor of Mining Engineering and a Consulting Engineer currently working at the University of Mines and Technology, Tarkwa, Ghana. He holds the degrees of MSc from the Moscow Mining Institute, Moscow, Russia, and $\mathrm{PhD}$ and DIC from the Imperial College of Science, Technology and Medicine, London, UK. He is a member of Institute of Materials, Minerals and Mining of UK and New York Academy of Sciences and also a fellow of Ghana Institution of Engineers and the Ghana Academy of Arts and Science. His research and consultancy works cover Mine Design and Planning, Mine Feasibility Study, Operations Research, Environmental Protection and Corporate Social Responsibility Management.

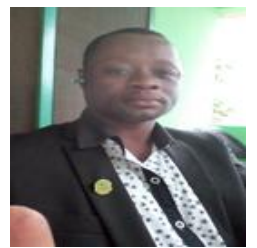

R. Gyebuni is a Mining Engineer currently lecturing at the University of Mines and Technology, Tarkwa, Ghana. He holds the degrees of MPhil and BSc from the University of Mines and Technology (UMaT), Tarkwa and Kwame Nkrumah University of Science and Technology (KNUST), Kumasi respectively. $\mathrm{He}$ is a $\mathrm{PhD}$ candidate at $\mathrm{UMaT}$. His research interest includes Operations Research, Mine Planning and Design, Mine Feasibility Studies, Corporate Social Responsibility Management and Occupational Health, Safety and Environmental Management. 